\title{
THE PSYCHOSOMATIC RELATIONSHIP BETWEEN COMBAT STRESS AND INJURIES (MONITORING RESULTS REPORT)
}

\author{
Hovhannisyan H. R., Tarjumanyan S. V. (Yerevan State University, \\ Yerevan, Armenia) \\ hrach.hovhannisyan@ysu.am, silvitarjumanyan@yahoo.com \\ Barseghyan A. A. ("Suggest Psychological Studio” NGO, Yerevan, Armenia) \\ suggeststudio@gmail.com \\ 乙tipluјшgर्uน uर्u. 31.07.2021 \\ 9pmpunuर्umध uर्u. 30.08.2021

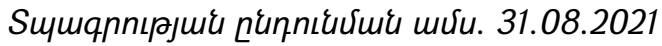

The study was conducted in real conditions while assisting military medical staff. Our psychological team working on a voluntary basis participated in the rehabilitation and psychological assessment of thousands of soldiers during the 44-day war and in the post-war period. In this work, we have made an attempt to address the assessment of soldiers' psychological conditions due to combat stress and post-stress conditions, depending on the nature of the trauma (injury or mental disorder). Accounting all these conditions allows us to more effectively and accurately assess soldiers' mental and physical health, to clarify the vectors of psycho-rehabilitation work, to predict further psychological shifts. The study revealed significant patterns of inverse correlation between physical injury and mental disorders, as well as some connections between the personal component and mental disorder.

Keywords: Combat stress, Psychological assessment, Psychological help, Defense mechanisms, Psycho-Somatic relations.

DOI: https://doi.org/10.46991/SBMP/2021.4.2.199

The article presents a key concept for modern mental and physical health disciplines in the current reality of Armenia. The study was conducted in real conditions while assisting military medical staff. Our psychological team working on a voluntary basis participated in the rehabilitation and psychological assessment of thousands of soldiers. During the 44-Day War that began on September 27, 2020 and after it, the necessary psychological assistance was provided to more than 10,000 servicemen in various professional groups in both civilian and military medical institutions of the republic. For the first time in the history of the Republic of Armenia, extensive psychological work was carried out with the servicemen who received various wounds and injuries.

In this work, we have made an attempt to address the assessment of soldiers' psychological conditions due to combat stress and post-stress conditions, depending 
on the degree of the injury or psychiatric diagnosis. Accounting all these conditions allows us to more effectively and accurately assess soldiers' mental and physical health, to clarify the vectors of psycho-rehabilitation work, to predict further psychological shifts.

During the sustained observations, we noticed some phenomena, which within the framework of medical-psychological explanation are described as manifestations of psychosomatic and somato-psychic connections. Our work in the psychiatric, surgical and therapeutic departments of the military hospital showed that the number of cases of mental disorders among the servicemen who received injuries or other physical injuries was insignificant. Similarly, the cases of physical injuries among soldiers with mental disorders make up a small percentage. Exposure to stress can lead to either adaptation or a breakdown in the body's physiological system. Di-stress can have a negative effect on cognitive processes, hindering the implementation of purposeful activities, as it can lead to pathological conditions, psychosomatic diseases.

It is a well-known fact that if the psychological defense mechanisms are disrupted for some reason, the probability of developing mental disorders increases sharply. But what happens when a person receives an expected physical injury (for example, a combat injury)? It is here that we observed an interesting phenomenon in terms of psychosomatic connections, which was the basis for our hypothesis. Later we conventionally called this phenomenon "artificial conversion". It is not that mental feelings are somatized through defense mechanisms, but the physical injury itself has activated (provoked) the defense mechanism of a person. It seems that the body has already taken on itself the factors that in normal life could become a mental disorder or be transformed from mental to physical (somatization).

The hypothesis of work: It is assumed that after stressful combat situations, physical and mental disorders are manifested by the law of inverse correlatiion. That is, if there is a physical injury, then the mental injury is less expressed in post-stress situations, and quite the opposite. Moreover, private patterns confirming the hypothesis have also been revealed.

Research methods.

The following qualitative methods were used in the research work:

1) Objective observation;

2) Documentary analysis (analysis of medical personal files);

3) Content analysis of the results of psycho-rehabilitation works.

Criteria for clinical protocol and surveying during the analysis of individual cases (In the military psychiatric department).

1. Diagnosis according to the referral.

2. Clinical diagnosis.

3. Date of admission and discharge. 

4. Heredity.
5. Traumatisation history.
6. Complaint.
7. Observation and examination.
8. The result of treatment.

The peculiarity of the assessment is that the psychological work done separately, its approaches, style and format differ significantly from the psychological work performed in collaboration with medical staff. The necessary psychological assistance to the wounded soldiers in a war situation is difficult due to the following circumstances.

- The period of medical care often does not coincide with the psychological one.

- Place of medical care and environmental conditions change frequently.

- The working hours for each patient are irregular.

- The psychological work is rapid and spontaneous, due to lack of time.

- It is difficult to maintain the principle of patient confidentiality.

- Systematic psychological work becomes impossible.

The study revealed significant patterns of inverse correlation between physical injury and mental disorders, as well as some of its characteristics of the personal component and mental disorder.

The applied results were contributed in the corresponding procedures of the medical institution.

CONCLUSION. We have come to the following conclusions based on the theoretical analysis and practical research.

1. The psychological condition of soldiers who have received physical injuries differs from that of soldiers with mental disorders.

- First, with the fluctuating nature of mental states. In the case of physical injuries, the mood is more variable with frequent changes.

- Secondly, in the case of physical injuries, psychopathological symptoms are almost absent.

2. Psychosomatic disorders in the post-stress period vary by the type of injury. Moreover, in the first days of the war (during the period of acute stress), the psychological and physical connections are mostly manifested by dissociated stupors.

3" The effects of the psychogenic factor after the combat stress have an individual expression.

4. During the war and after the ceasefire, in terms of psychodiagnostics, two types of diagnoses are distinguished: post-traumatic stress disorder (PTSD) and dissociative conversion disorders. The root goes to the nature of the person, it means, that the personality accentuation can be decisive in the diagnosis, whether it is a dissociative conversion disorder or PTSD. People with particularly hysterical 
accentuation respond to the strongest stress with dissociative disorders, and "Thinkers" (according to psychological types by K. G. Jung) are more likely to be subjected to severe PTSD with feelings of self-blame, frustration and intolerance of loss.

5. Through physical injury and pain, an "artificial conversion" seems to take place, serving as a unique somatopsychic buffer.

Thus, our hypothesis confirms that after stressful combat situations, physical and mental disorders are manifested by the law of inverse correlatiion. That is, if there is a physical injury, then the mental injury is less expressed in post-stress situations, and quite the opposite. Moreover, private patterns confirming the hypothesis have also been revealed. An important factor is the psychological preconditions that will contribute to further recovery and healing. As psychological work is necessary not only for the regulation of mental states, but also for the effectiveness of physical health recovery and adaptation, so there is a need for psychological assessment, regulation and guidance. For this, the authors provide some sources in the references which can help a process of psychological service.

Special thanks to the medical staff of the Yerevan "Kanaz" Military Hospital, in particular to the psychiatric team for their joint work and professional support.

\section{References}

1. Cramer Ph. Protecting the Self: Defense Mechanisms in Action, The Guilford Press, 2006.

2. Hovhannisyan H., Barseghyan A. LEVITAS: Psycho-Regulatory Trainings _ Yerevan. 2019.

3. Kramer U. Coping and defense mechanisms: What's the difference? Second act. Psychotherapy: Theory, Research and practice psychology, 83(2), 2010, pg. 207-221.

4. Larsen A., Bøggild H., Mortensen J., Foldager L., Hansen J., Christensen A., Munk Jørgensen P. Psychopathology, defense mechanisms and the psychosocial work environment._ Psychiatry, 56(6), 2010, pg. 563-577.

5. Olson T. R., Perry J., Janzen J. I., Petraglia J., \& Presniak M. D. Addressing and interpreting defense mechanisms in psychotherapy: General considerations. Psychiatry: Interpersonal and Biological Processes, 74(2), 2011, pg. 142-165.

6. Александер Ф. психосоматическая медицина. Принципы и практическое применение, Изд-во ЭКСМО-Пресс, Серия «Психология без границ", 2002.

7. Фрейд А. Психология Я и защитные механизмы: Педагогика, Москва. 1993. 


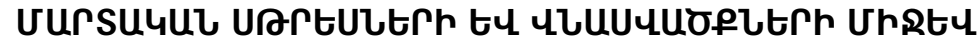

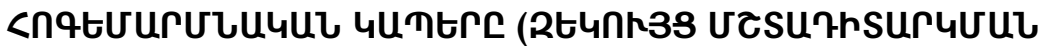 uกา3กhしคไtrh UUUhし)}

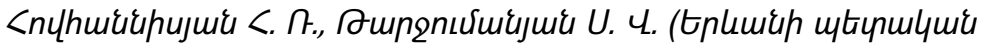

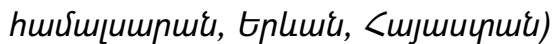

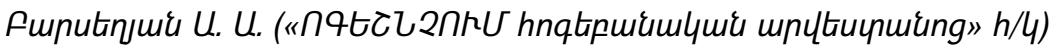

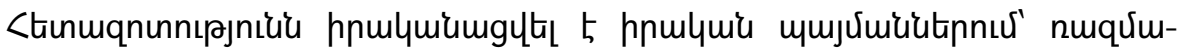

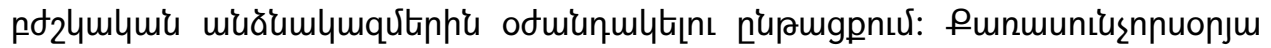

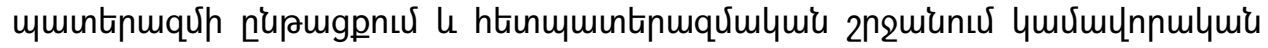

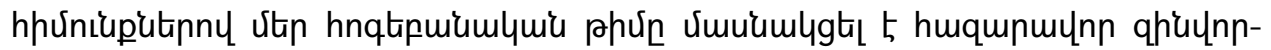

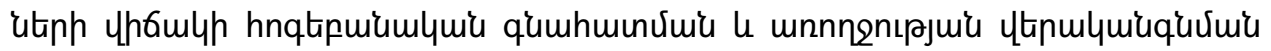
m2fumunuiuputiphis:

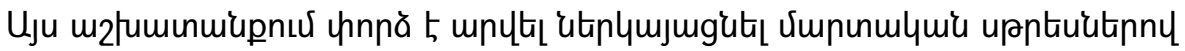

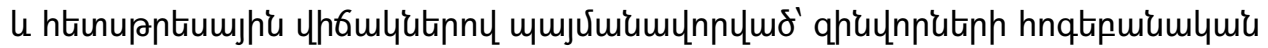

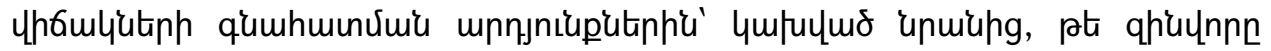

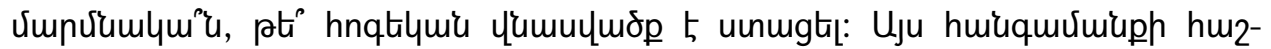

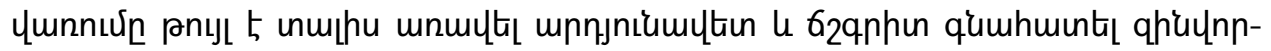

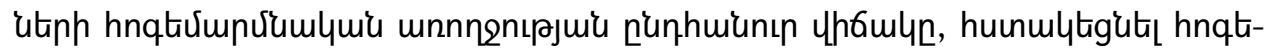

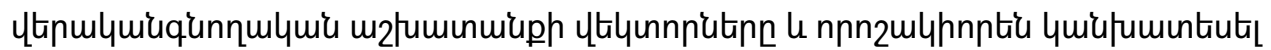

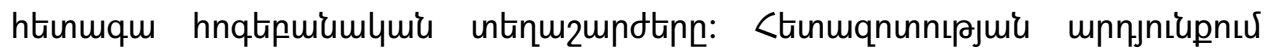

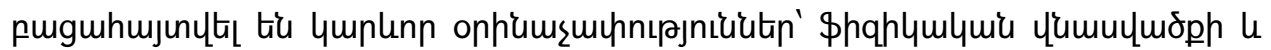

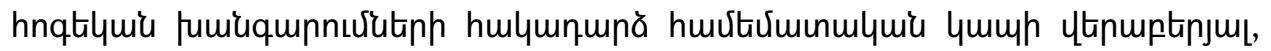

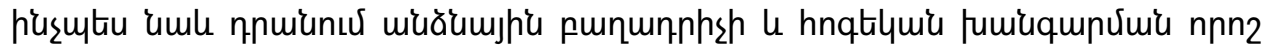
ymutin:

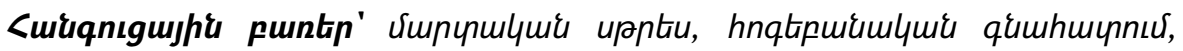

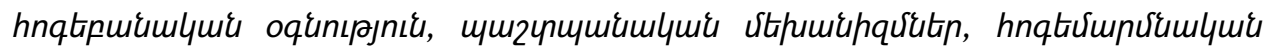
qumetr:

\section{ПСИХО-СОМАТИЧЕСКАЯ СВЯЗЬ МЕЖДУ БОЕВЫМИ СТРЕССАМИ И ТРАВМАМИ (ОТЧЕТ О РЕЗУЛЬТАТАХ МОНИТОРИНГА)}

Оганнесян Г. Р., Тарджуманян С. В. (Ереванский Государственный

Университет, Ереван, Армения)

Барсегян А. A. ("Suggest Psychological Studio" Общ. Орг., Ереван, Армения)

Исследование проводилось в реальных условиях при оказании помощи военно-медицинскому персоналу. Наша психологическая команда, работающая на общественных началах, участвовала в реабилитации и психологической оценке тысяч солдат во время 44-дневной войны и в послевоенный период. В 
этой работе мы попытались представить результаты оценки психологического состояния солдат из-за боевого стресса и постстрессовых состояний, в зависимости от характера травмы (телесного либо психического). Учет этого обстоятельства позволяет более эффрективно и точно оценивать психическое и физическое здоровье солдат, уточнить векторы психореабилитационной работы, прогнозировать дальнейшие психологические сдвиги. Исследование выявило значительные связи обратной корреляции между фризическими повреждениями и психическими расстройствами, а также некоторые связи между личностного компонента и психических расстройств.

Ключевые слова: боевой стресс, психологическая оценка, психологическая помощь, защитные механизмы, психосоматические связи. 